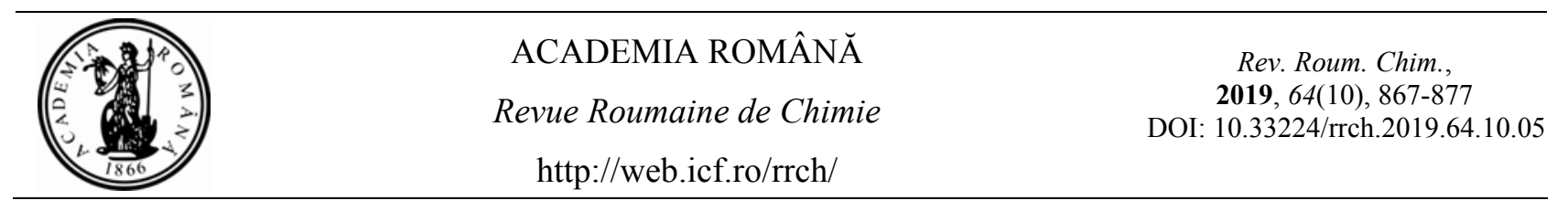

\title{
MODIFIED GRAPHITE/GRAPHENE DOT MICROSENSORS FOR THE ASSAY OF TRACE AMOUNTS OF LEAD AND CADMIUM IN WATER CATCHMENTS AREAS USING DIFFERENTIAL PULSE ANODIC STRIPPING VOLTAMMETRY
}

\author{
Jacobus Frederick VAN STADEN* ${ }^{*}$ and Georgiana-Luiza ARNOLD TATU
}

Process Analytical Technology Laboratory (PATLAB) Bucharest, National Institute of Research and Development for Electrochemistry and Condensed Matter (INCDEMC), 202 Splaiul Independenței Str., Bucharest 060021, Roumania

In this study, dot microsensors based on graphite/graphene paste modified with iron (II) phthalocyanine, nickel (II) phthalocyanine and $5,10,15,20$-tetra(4pyridyl) $21 \mathrm{H}, \quad 23 \mathrm{H}$ porphine chloride tetrakis(methochloride) manganese(III) were used for the determination of trace amounts of lead and cadmium from various water catchments areas using differential pulse anodic stripping voltammetry. The response of the proposed dot microsensors were sensitive
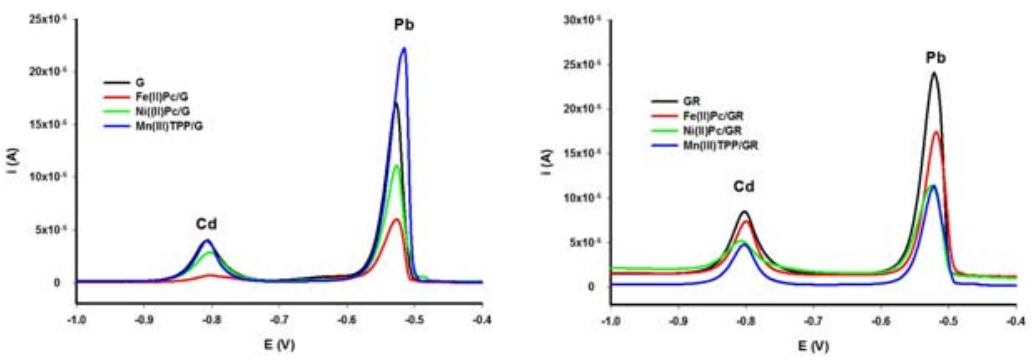
enough to detect very low levels of both metals ions in drinking water resources to take corrective action for the supply of safe and suitable drinking water. The lowest limits of quantification for lead is $0.00207 \mu \mathrm{g} \mathrm{L}^{-1}$ and for cadmium $5.6 \mu \mathrm{g} \mathrm{L}{ }^{-1}$, with a correlation coefficient $\left(\mathrm{R}^{2}\right)$ between 0.9951 and 0.9981 for lead, and between 0.9951 and 0.9984 for cadmium. The recovery of $\mathrm{Pb}(\mathrm{II})$ and $\mathrm{Cd}(\mathrm{II})$ in water samples were higher than $93.06 \%$ with $\mathrm{RSD}(\%)$ values lower than $0.29 \%$. These results of the proposed dot microsensors compared favorably with the results from a standard ISO certified method.

\section{INTRODUCTION}

Exposure to various chemicals including transition and heavy metals occurs every day through multiple routes such as ingestion, inhalation, and skin contact and via the umbilical cord to the unborn child. Many chemicals and metals are harmless or even beneficial; others are a threat to our health and to the environment. There is a continuous increase production and pollution of these substances and subsequently the potential for chemical exposure. These substances are risky and hazardous to human health with possible development of allergies, tumors and serious diseases and exposure could potentially be reduced or removed through environmental management with careful monitoring of metals like $\mathrm{Cd}$ and $\mathrm{Pb}$. Water is essential for life. The amount of fresh water on earth is limited, and its quality is under constant pressure. Preserving the quality of fresh water is important for the drinking-water supply, food production and recreational water use. According to World Health Organization's (WHO) the maximum level for $\mathrm{Pb}^{2+}$ and $\mathrm{Cd}^{2+}$ ions in drinking water is $10 \mu \mathrm{g} \mathrm{L} \mathrm{L}^{-1}$ and $3 \mu \mathrm{g} \mathrm{\textrm {L } ^ { - 1 }}$. According to WHO and U.S. Environmental Protection Agency (EPA) the maximum level of $\mathrm{Pb}$ and $\mathrm{Cd}$ is 50 and $10 \mu \mathrm{gL}^{-1}$, respectively. ${ }^{1-7}$

\footnotetext{
*E-mail addresses: koosvanstaden2012@yahoo.com, koosvanstaden2012@gmail.com, Tel: +40748137871,www.patlab.ro
} 
Cadmium is a toxic metal with a half-life of 1030 years, being classified in the list of carcinogens in group 1.,9 The main source of cadmium contamination is food. A disease caused by cadmium is the Itai Itai disease, which first appeared in Japan. ${ }^{10,11}$ Cadmium is, also, associated with breast cancer, chronic renal disease, ${ }^{12,13}$ and prostate cancer. ${ }^{14}$ No treatment against cadmium intoxication is known, but recent studies in rats have shown that Tinospora Cordifolia extract attenuates biochemical and histological changes induced by cadmium. ${ }^{15}$ Lead is a toxic metal that leads to Parkinson's disease, urological (kidney) disease. The treatment used is that of zinc supplements, meso-2,3-dimercaptosuccinic acid, 2,3-dimercapto-propanesulfonic acid, dimercaptopropanol. ${ }^{16-23}$

The widely used and standard techniques for analysis of heavy metals are spectrometric procedures (graphite furnace atomic absorption spectroscopy, flame atomic absorption spectrometry, inductively coupled plasma mass spectrometry, atomic fluorescence spectrometry, inductively coupled plasma atomic emission spectroscopy), or chromatography methods (gas chromatography, high performance liquid chromatography, etc.). All these methods require complex equipment, are expensive to maintain, and need well trained people. ${ }^{24-30}$

Recently, new electrochemical methods have been developed for the detection of heavy metals. ${ }^{31,32}$ The glassy carbon electrode is the most commonly used, usually modified with $\mathrm{NiO}$ morphologies consisting of rods $\mathrm{NiO}$, flakes $\mathrm{NiO}$ and balls $\mathrm{NiO}^{33}$, with mercury film, ${ }^{34}$ screen printed electrodes modified with bismuth, ${ }^{35-38}$ or screen printed electrodes modified with some organic compounds such as: dibenzo-24-crown-8, tetrathiacyclododecane 12 -crown- $4,{ }^{39}$ crown-ether based membrane, ${ }^{40}$ glutathione. ${ }^{41}$

We herewith developed a simple, sensitive and selective electrochemical method for the determination of cadmium and lead ions in water. The article presents a procedure with modified dot microsensors based on graphite/graphene paste for the detection of cadmium and lead ions from various water catchments areas (e.g., fresh water, underground water, geothermal waste water) using differential pulse anodic stripping voltammetry (DPASV).

\section{MATERIALS AND METHODS}

\section{Reagents and instrumentation}

$\mathrm{Cd}\left(\mathrm{NO}_{3}\right)_{2} \cdot 4 \mathrm{H}_{2} \mathrm{O}, \mathrm{Pb}\left(\mathrm{NO}_{3}\right)_{2}, \mathrm{KCl}, \mathrm{NaCl}, \mathrm{NaNO}_{3}$, $\mathrm{NaH}_{2} \mathrm{PO}_{4} \cdot \mathrm{H}_{2} \mathrm{O}, \mathrm{Na}_{2} \mathrm{HPO}_{4}$ for the preparation of the solutions were purchased from Sigma-Aldrich. Graphite (G) and graphene (GR) were supplied by Sigma Aldrich, and paraffin oil by Fluka (Buchs, Sweden). Iron(II) phthalocyanine (Fe(II)Pc), nickel(II) phthalocyanine (Ni(II)Pc) and manganese(III) 5,10,15,20-tetra(4-pyridyl)-21H,23Hporphine chloride tetrakis(methochloride) (Mn(III)TPP) were from Aldrich.

Phosphate buffer solutions (PBS, $0.1 \mathrm{~mol} \mathrm{~L}^{-1}$ ) with $\mathrm{pH}=2-10$ were prepared by using different ratios between $\mathrm{NaH}_{2} \mathrm{PO}_{4}$ and $\mathrm{Na}_{2} \mathrm{HPO}_{4}$. Hydrogen chloride $\left(\mathrm{HCl}, 0.1 \mathrm{~mol} \mathrm{~L}^{-1}\right)$ and sodium hydroxide $\left(\mathrm{NaOH}, 0.1 \mathrm{~mol} \mathrm{~L}^{-1}\right)$ were used for $\mathrm{pH}$ adjustment.

The standard solutions for differential pulse voltammetry (DPV) were prepared using $10^{-3} \mathrm{~mol}$ $\mathrm{L}^{-1}$ of $\mathrm{Cd}^{2+}$ or $\mathrm{Pb}^{2+}$ as stock solutions. All standard solutions of $\mathrm{Cd}^{2+}$ or $\mathrm{Pb}^{2+}\left(10^{-4}-10^{-12} \mathrm{~mol} \mathrm{~L}^{-1}\right)$ were prepared from the stock solution by serial dilution, with phosphate buffer solution (PBS) of different pHs containing $\mathrm{KCl}, \mathrm{NaCl}$ or $\mathrm{NaNO}_{3}\left(0.1 \mathrm{~mol} \mathrm{~L}^{-1}\right)$ as supporting electrolytes.

All solutions were prepared using deionized water obtained from a Direct-Q 3 Water Purification System (Millipore Corporation, France).

All measurements were recorded using a PGSTAT $128 \mathrm{~N}$ potentiostat/galvanostat connected to a three electrode cell, and linked to a computer via an Eco Chemie (Utretch, The Netherlands) software version 4.9. $\mathrm{An} \mathrm{Ag} / \mathrm{AgCl}$ electrode served as reference electrode and a platinum electrode served as auxiliary electrode, new developed sensors served as working electrode in the electrochemical cell. The $\mathrm{pH}$ measurements were performed using a CyberScan PCD 6500 Multiparameter.

DPV curves have been recorded at $0.01 \mathrm{~V} \mathrm{~s}^{-1}$, with a pulse height of $0.025 \mathrm{~V}$ and step potential of $0.05 \mathrm{~V}$.

All measurements were performed at $25^{\circ} \mathrm{C}$.

\section{Design of dot microsensors}

Graphite or graphene pastes were modified with iron(II) phthalocyanine (Fe(II)Pc), nickel(II) phthalocyanine (Ni(II)Pc) and manganese(III) 5,10,15,20-tetra(4-pyridyl)-21H,23H-porphine chloride tetrakis(methochloride) (Mn(III)TPP) each. The modified graphite or graphene pastes were prepared as follows: $100 \mathrm{mg}$ of graphite or graphene powder were mixed with $30 \mathrm{~mL}$ paraffin oil to form the graphite or graphene pastes. $25 \mathrm{~mL}$ from the solution of $\mathrm{Fe}(\mathrm{II}) \mathrm{Pc}\left(10^{-3} \mathrm{~mol} \mathrm{~L}^{-1}\right.$, prepared in dimethyl sulfoxide) or $\mathrm{Ni}(\mathrm{II}) \mathrm{Pc}\left(10^{-3}\right.$ mol L ${ }^{-1}$, prepared in $\mathrm{N}, \mathrm{N}$-dimethylformamide) or Mn(III)TPP $\left(10^{-3} \mathrm{~mol} \mathrm{~L}^{-1}\right.$, prepared in dimethyl sulfoxide) was added to the graphite or graphene pastes mixed with $25 \mathrm{~mL}$ paraffin oil. The 
modified paste was placed into a very small plastic tube. Electrical contact was obtained with an $\mathrm{Ag}$ wire inserted into the paste. The surface of the electrode can be renewed by polishing with alumina paper. When not in use, the dot microsensors were stored in a dry place, away from day light and at room temperature.

\section{RESULTS AND DISCUSSION}

\section{Optimization of working conditions}

DPV curves $\left(0.01 \mathrm{~V} \mathrm{~s}^{-1}\right)$ were recorded in order to optimize the working conditions for $G$, $\mathrm{Fe}(\mathrm{II}) \mathrm{Pc} / \mathrm{G}, \quad \mathrm{Ni}(\mathrm{II}) \mathrm{Pc} / \mathrm{G}, \quad \mathrm{Mn}(\mathrm{III}) \mathrm{TPP} / \mathrm{G}, \quad \mathrm{GR}$, $\mathrm{Fe}(\mathrm{II}) \mathrm{Pc} / \mathrm{GR}, \mathrm{Ni}$ (II)Pc/GR, $\mathrm{Mn}$ (III)TPP/GR dot microsensors, using a $10^{-6} \mathrm{~mol} \mathrm{~L}^{-1}$ solution of $\mathrm{Cd}^{2+}$ or $\mathrm{Pb}^{2+}$ ions. Three different supporting electrolytes were tested $\left(0.1 \mathrm{~mol} \mathrm{~L}^{-1} \mathrm{NaCl}, 0.1 \mathrm{~mol} \mathrm{~L}^{-1}\right.$ $\mathrm{KCl}$ and $0.1 \mathrm{~mol} \mathrm{~L}^{-1} \mathrm{KNO}_{3}$ ) in PBS $\mathrm{pH}=2-10$. Figure 1 shows the effect of $\mathrm{pH}$ and supporting electrolyte on the peak height for each sensor, using a solution of $10^{-6} \mathrm{~mol} \mathrm{~L}^{-1} \mathrm{Cd}^{2+}$ ions, and for a solution of $10^{-6} \mathrm{~mol} \mathrm{~L}^{-1} \mathrm{~Pb}^{2+}$ ions. The sensor

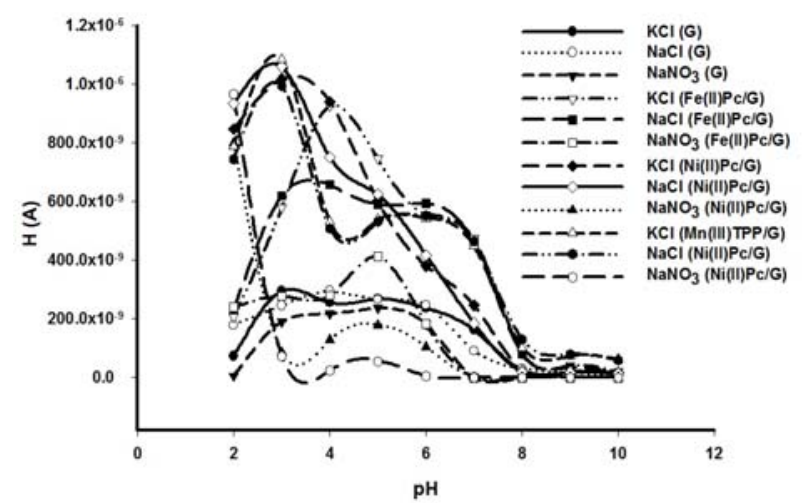

A

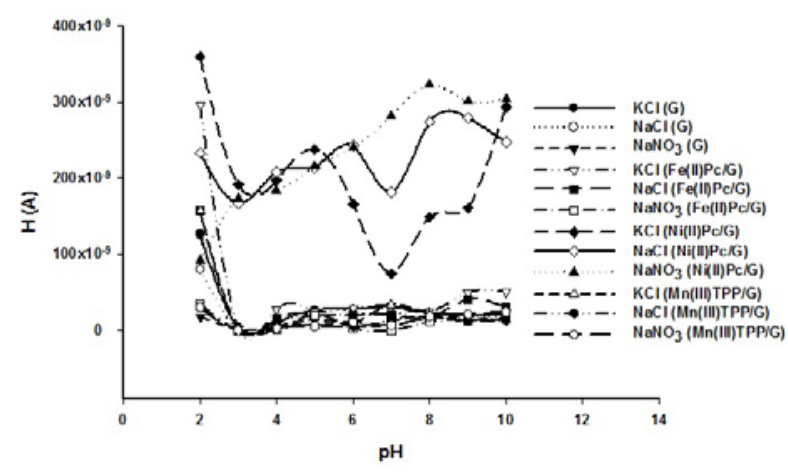

C sensitivity increases towards lower $\mathrm{pH}$ solutions. The following experimental conditions were used with the following eight dot microsensors for the working solution of $10^{-6} \mathrm{~mol} \mathrm{~L}^{-1} \mathrm{Cd}^{2+}$ ions. For $\mathrm{Fe}(\mathrm{II}) \mathrm{Pc} / \mathrm{GR}, \quad \mathrm{Ni}(\mathrm{II}) \mathrm{Pc} / \mathrm{GR}, \quad \mathrm{Mn}(\mathrm{III}) \mathrm{TPP} / \mathrm{GR}$ dot microsensors the optimum performance were obtained in a $0.1 \mathrm{~mol} \mathrm{~L}^{-1} \mathrm{KCl}$, PBS $\mathrm{pH}=2$ solution. For the unmodified graphite dot microsensor the optimal response was obtained using a $0.1 \mathrm{~mol} \mathrm{~L}^{-1} \mathrm{KCl}$, $\mathrm{PBS} \mathrm{pH}=3$ solution, and for the $\mathrm{Fe}(\mathrm{II}) \mathrm{Pc} / \mathrm{G}$ sensor $0.1 \mathrm{~mol} \mathrm{~L}^{-1} \mathrm{KCl}$, PBS pH $=4$ solution. For $\mathrm{Ni}(\mathrm{II}) \mathrm{Pc} / \mathrm{G}$ and $\mathrm{Mn}(\mathrm{III}) \mathrm{TPP} / \mathrm{G}$ dot microsensors we observed that two supporting electrolytes gave a good response: $0.1 \mathrm{~mol} \mathrm{~L}^{-1} \mathrm{KCl}$, PBS $\mathrm{pH}=3$ or $0.1 \mathrm{~mol} \mathrm{~L}^{-1} \mathrm{NaCl}$, PBS $\mathrm{pH}=2,3$. Unmodified graphene dot microsensor have, also, a good response for two supporting electrolytes: 0.1 mol L ${ }^{-1} \mathrm{NaCl}, \mathrm{PBS} \mathrm{pH}=3$ or $0.1 \mathrm{~mol} \mathrm{~L}^{-1} \mathrm{NaNO}_{3}$, PBS $\mathrm{pH}=2$. In the case of $\mathrm{Pb}^{2+}$ ions, all sensors, except $\mathrm{Ni}(\mathrm{II}) \mathrm{Pc} / \mathrm{GR}$, gave the best response using a $0.1 \mathrm{~mol} \mathrm{~L}^{-1} \mathrm{KCl}$, PBS $\mathrm{pH}=2$ solution. $\mathrm{Ni}(\mathrm{II}) \mathrm{Pc} / \mathrm{GR}$ sensors has a similar response in a $0.1 \mathrm{~mol} \mathrm{~L}^{-1} \mathrm{KCl}, \mathrm{PBS} \mathrm{pH}=2$ or $0.1 \mathrm{~mol} \mathrm{~L}^{-1} \mathrm{NaCl}$, $\mathrm{PBS} \mathrm{pH}=2$.

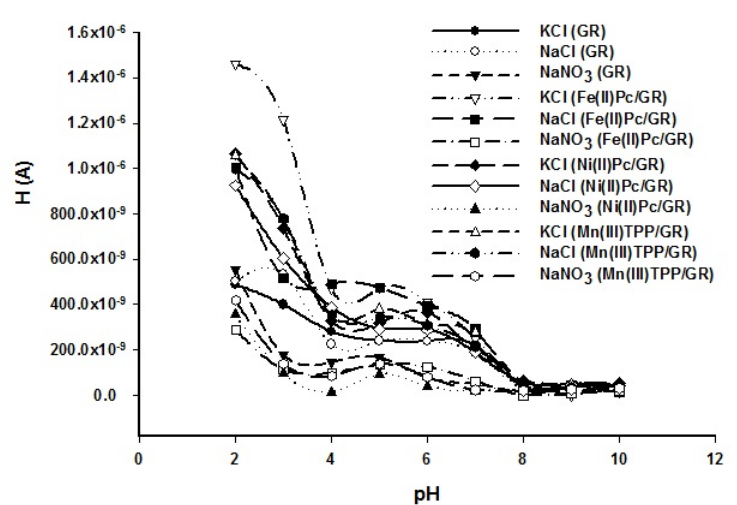

B

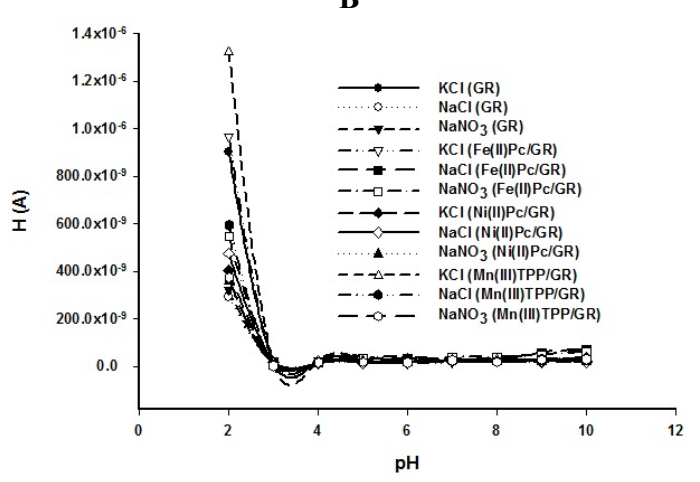

D

Fig. 1 - The effect of electrolyte and $\mathrm{pH}$ on the peak height for a concentration of a) and b) $\mathrm{Cd}^{2+}$ solution of $10^{-6}$ mol $\mathrm{L}^{-1}$ unmodified graphite/graphene and modified graphite/graphene dot microsensors; c) and d) $\mathrm{Pb}^{2+}$ solution of $10^{-6} \mathrm{~mol} \mathrm{~L}^{-1}$ unmodified graphite/grapheme and modified graphite/graphene dot microsensors. 


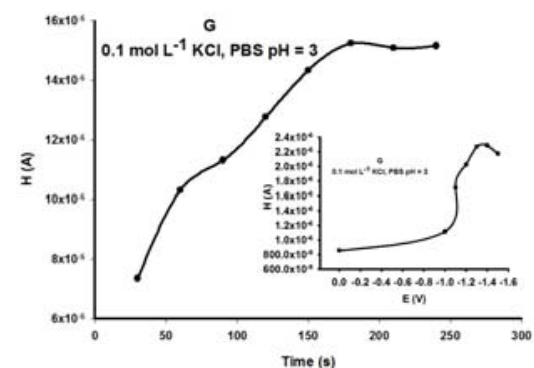

a
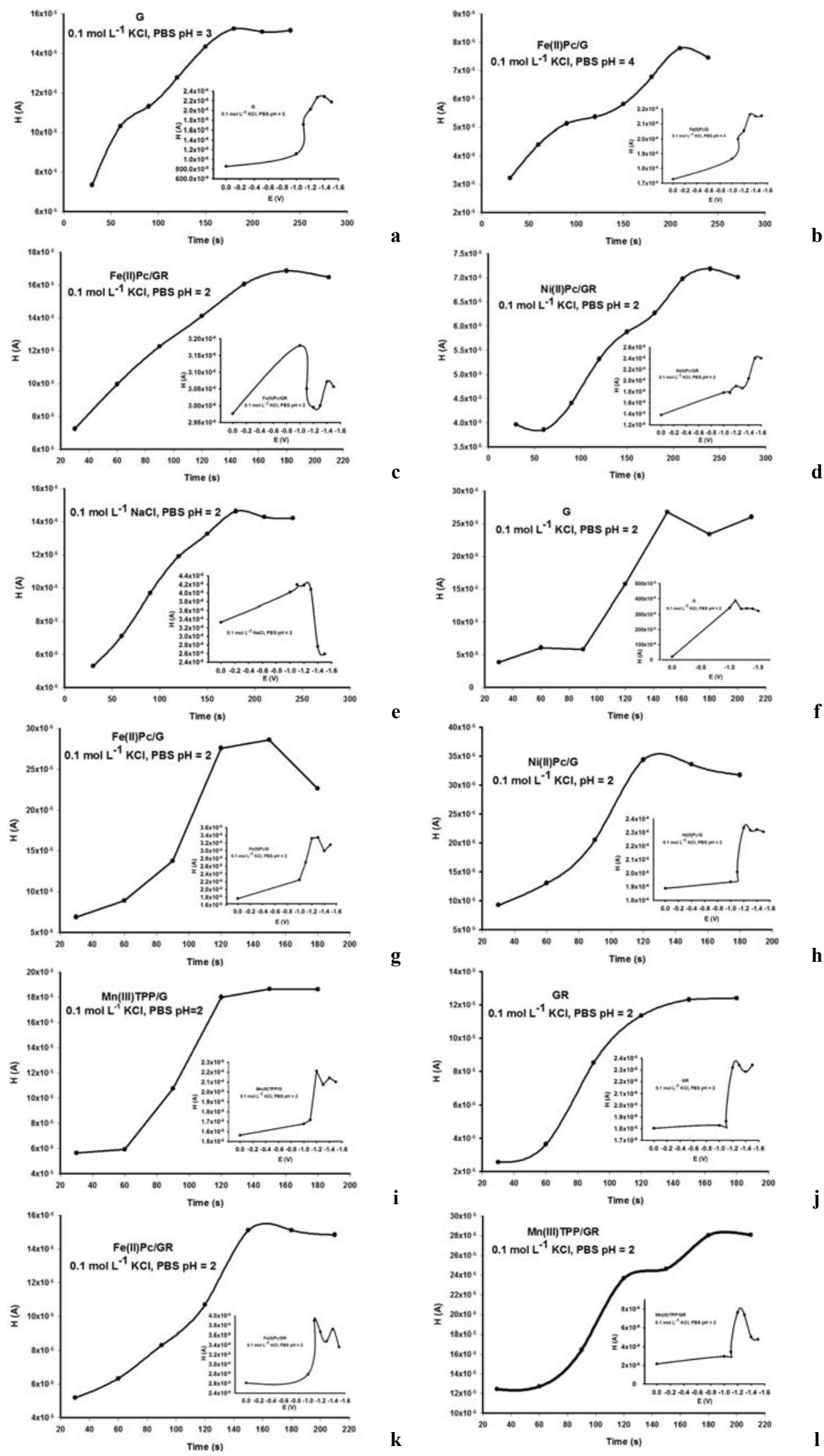

Fig. 2 - Influence of the deposition time for a) G, b) Fe(II)Pc/G, c) Fe(II)Pc/GR, d) Ni(II)Pc/GR, e) Mn(III)TPP/GR dot microsensors using a $10^{-6} \mathrm{~mol} \mathrm{~L}^{-1} \mathrm{Cd}^{2+}$ solution and for f) $\mathrm{G}$, g) Fe(II)Pc/G, h) Ni(II)Pc/G, i) Mn(III)TPP/G, j) GR, k) Fe(II)Pc/GR, l) Mn(III)TPP/GR dot microsensors using a $10^{-6} \mathrm{~mol} \mathrm{~L}^{-1} \mathrm{~Pb}^{2+}$ solution; inset: deposition potential, where $\mathrm{H}$ is the peak height $(\mathrm{A})$. 

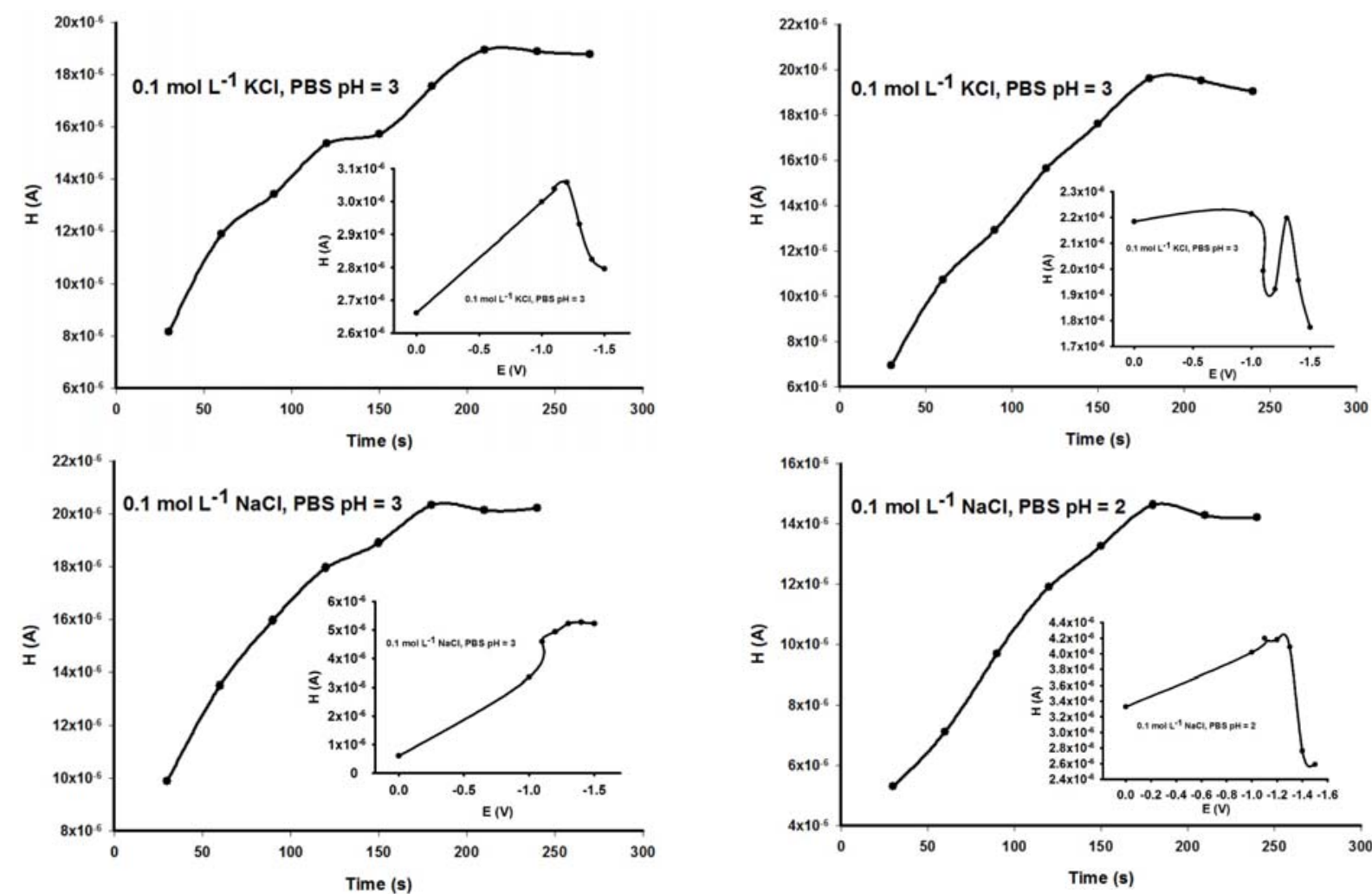

a
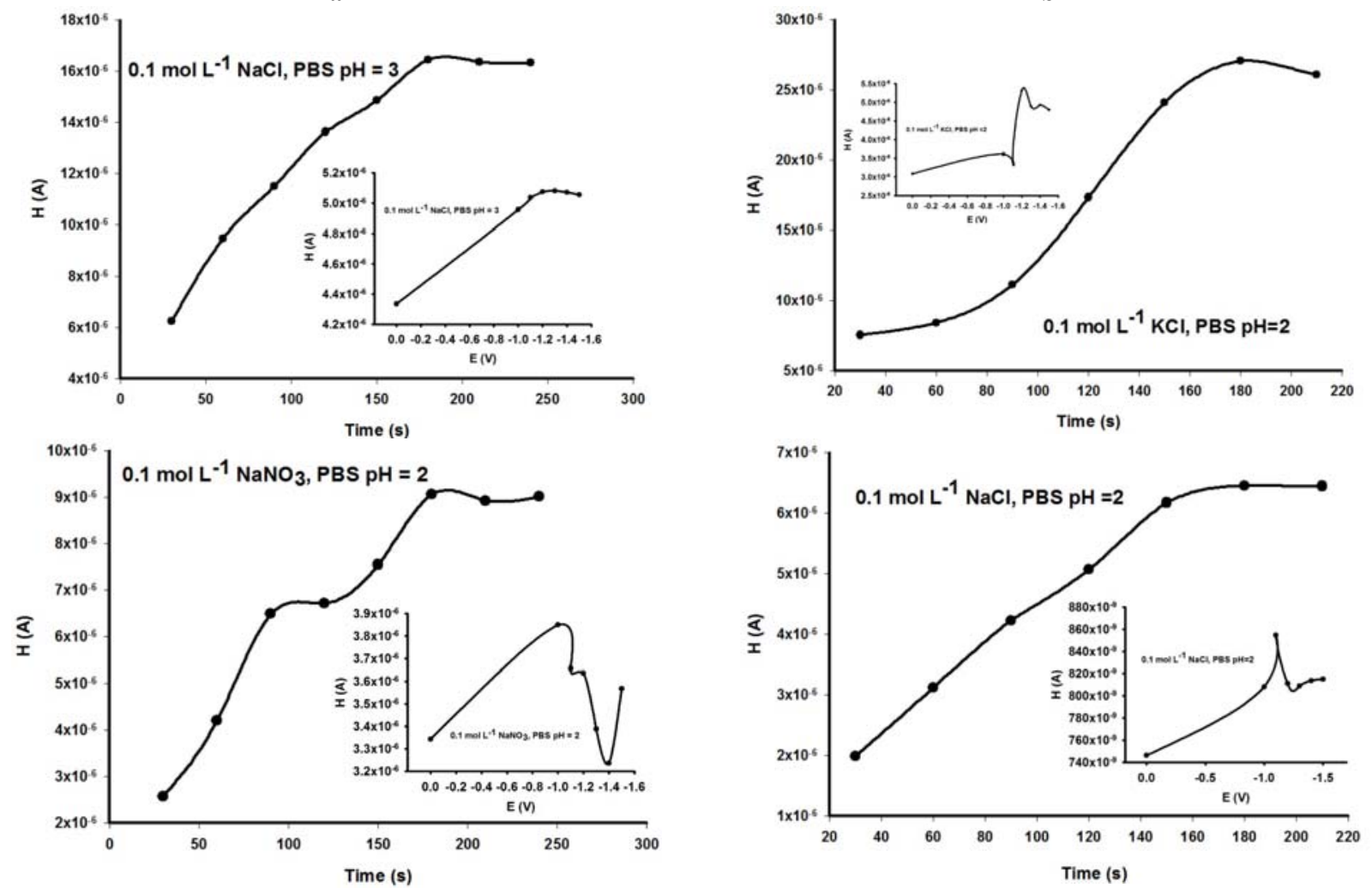

c

d

Fig. 3 - Influence of the deposition time for a) Ni(II)Pc/G, b) Mn(III)TPP/G, c) GR dot microsensors using a $10^{-6} \mathrm{~mol} \mathrm{~L}^{-1} \mathrm{Cd}^{2+}$ solution; d) $\mathrm{Ni}(\mathrm{II}) \mathrm{Pc} / \mathrm{GR}$ dot microsensors using a $10^{-6} \mathrm{~mol} \mathrm{~L}^{-1} \mathrm{~Pb}^{2+}$ solution; inset: deposition potential, using different supporting electrolyte where $\mathrm{H}$ is the peak height (A). 
Table 1

Optimum experimental conditions

for the $\mathrm{Cd}^{2+} 10^{-6} \mathrm{~mol} \mathrm{~L}^{-1}$ and $\mathrm{Pb}^{2+} 10^{-6} \mathrm{~mol} \mathrm{~L}^{-1}$ with different modified graphite and graphene dot microsensors

\begin{tabular}{|c|c|c|c|c|c|}
\hline $\begin{array}{l}\text { Heavy } \\
\text { metal }\end{array}$ & $\begin{array}{ll} & \text { Parameter } \\
\text { Sensors } & \end{array}$ & $\begin{array}{c}\text { PBS } \\
\text { pH }\end{array}$ & $\begin{array}{l}\text { Supporting } \\
\text { electrolyte }\end{array}$ & $\begin{array}{l}\text { Reduction } \\
\text { Time (V) }\end{array}$ & $\begin{array}{c}\text { Deposition } \\
\text { Time (s) }\end{array}$ \\
\hline \multirow{8}{*}{$\mathrm{Cd}^{2+}$} & $\mathrm{G}$ & 3 & $\mathrm{KCl}$ & -1.4 & 180 \\
\hline & $\mathrm{Fe}(\mathrm{II}) \mathrm{Pc} / \mathrm{G}$ & 4 & $\mathrm{KCl}$ & -1.3 & 210 \\
\hline & $\mathrm{Ni}(\mathrm{II}) \mathrm{Pc} / \mathrm{G}$ & 3 & $\mathrm{NaCl}$ & -1.4 & 180 \\
\hline & Mn(III)TPP/G & 3 & $\mathrm{KCl}$ & -1 & 180 \\
\hline & GR & 3 & $\mathrm{NaCl}$ & -1.3 & 210 \\
\hline & $\mathrm{Fe}(\mathrm{II}) \mathrm{Pc} / \mathrm{GR}$ & 2 & $\mathrm{KCl}$ & -1 & 180 \\
\hline & $\mathrm{Ni}(\mathrm{II}) \mathrm{Pc} / \mathrm{GR}$ & 2 & $\mathrm{KCl}$ & -1.5 & 240 \\
\hline & $\mathrm{Mn}(\mathrm{III}) \mathrm{TPP} / \mathrm{GR}$ & 2 & $\mathrm{KCl}$ & -1.2 & 150 \\
\hline \multirow{8}{*}{$\mathrm{Pb}^{2+}$} & $\mathrm{G}$ & 2 & $\mathrm{KCl}$ & -1.1 & 150 \\
\hline & $\mathrm{Fe}(\mathrm{II}) \mathrm{Pc} / \mathrm{G}$ & 2 & $\mathrm{KCl}$ & -1.2 & 150 \\
\hline & $\mathrm{Ni}(\mathrm{II}) \mathrm{Pc} / \mathrm{G}$ & 2 & $\mathrm{KCl}$ & -1.2 & 180 \\
\hline & Mn(III)TPP/G & 2 & $\mathrm{KCl}$ & -1.2 & 150 \\
\hline & GR & 2 & $\mathrm{KCl}$ & -1.2 & 150 \\
\hline & $\mathrm{Fe}(\mathrm{II}) \mathrm{Pc} / \mathrm{GR}$ & 2 & $\mathrm{KCl}$ & -1.2 & 150 \\
\hline & $\mathrm{Ni}(\mathrm{II}) \mathrm{Pc} / \mathrm{GR}$ & 2 & $\mathrm{KCl}$ & -1.2 & 180 \\
\hline & Mn(III)TPP/GR & 2 & $\mathrm{KCl}$ & -1.2 & 180 \\
\hline
\end{tabular}

\section{Optimization of deposition time and potential for maximum response}

In order to obtain the maximum response of the dot microsensors, parameters like deposition potential and deposition time were optimized. Figures 2 and 3 show the influence of the deposition time with the corresponding position potential of the response of the dot microsensors using the best selected supporting electrolyte for each dot microsensor. For the sensors $\mathrm{G}, \mathrm{Fe}(\mathrm{II}) \mathrm{Pc} / \mathrm{G}$, $\mathrm{Fe}(\mathrm{II}) \mathrm{Pc} / \mathrm{GR}, \mathrm{Ni}(\mathrm{II}) \mathrm{Pc} / \mathrm{GR}, \mathrm{Mn}$ (III)TPP/GR only one supporting electrolyte was used in a $10^{-6} \mathrm{~mol} \mathrm{~L}^{-1}$ solution of $\mathrm{Cd}^{2+}$. In the case of $\mathrm{Ni}(\mathrm{II}) \mathrm{Pc} / \mathrm{G}$, $\mathrm{Mn}(\mathrm{III}) \mathrm{TPP} / \mathrm{G}$, GR, these parameters were determined using two supporting electrolytes, in order to have the optimum response for the determination of $\mathrm{Cd}^{2+}$. In the case of $\mathrm{Pb}^{2+}$ optimization, only one sensor (Ni(II)Pc/GR) with two supporting electrolytes were used for optimization of deposition potential with corresponding position time. Furthermore for maximum response of $\mathrm{Pb}^{2+}$, using a $10^{-6} \mathrm{~mol} \mathrm{~L}^{-1} \mathrm{~Pb}^{2+}$ solution with $\mathrm{G}, \mathrm{Fe}(\mathrm{II}) \mathrm{Pc} / \mathrm{G}$, $\mathrm{Ni}(\mathrm{II}) \mathrm{Pc} / \mathrm{G}, \quad \mathrm{Mn}(\mathrm{III}) \mathrm{TPP} / \mathrm{G}, \quad \mathrm{GR}, \quad \mathrm{Fe}(\mathrm{II}) \mathrm{Pc} / \mathrm{GR}$, $\mathrm{Mn}$ (III)TPP/GR dot microsensors only one supporting electrolyte was used. Table 1 presents the final results for the deposition potential, for the deposition time and showed the supporting electrolyte used for the calibration curve and for various water catchments areas for $\mathrm{Cd}^{2+}$ ions and for $\mathrm{Pb}^{2+}$ ions.

\section{Response characteristics for the $\mathrm{Cd}^{2+}$ and $\mathrm{Pb}^{2+}$ ions}

Figures 4 and 5, as well as Table 2 presents the response characteristics for the $\mathrm{Cd}^{2+}$ and $\mathrm{Pb}^{2+}$ ions using the optimal parameters (supporting electrolyte, deposition potential and deposition time). It can be seen that for all sensors good correlation coefficients were obtained. The highest sensitivity for the sensors was recorded for $\mathrm{Pb}^{2+}$ ions when compared with the determination for the $\mathrm{Cd}^{2+}$ ions. Dot microsensors based on unmodified graphite and modified graphite with $\mathrm{Ni}(\mathrm{II}) \mathrm{Pc}$ have the highest sensitivity for the determination of $\mathrm{Cd}^{2+}$

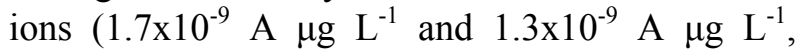
respectively).

The highest sensitivity, in case of determination of $\mathrm{Pb}^{2+}$ ions, was obtained with the dot microsensor based on graphene modified with $\mathrm{Ni}(\mathrm{II}) \operatorname{Pc}\left(8.7 \times 10^{-7} \mathrm{~A} \mu \mathrm{g} \mathrm{L} \mathrm{L}^{-1}\right)$.

The lowest limit of quantification was obtained for the graphite sensor modified with $\mathrm{Fe}(\mathrm{II}) \mathrm{Pc}$, for the determinations of $\mathrm{Cd}^{2+}\left(5.6 \mu \mathrm{g} \mathrm{L}^{-1}\right)$ and $\mathrm{Pb}^{2+}$ $\left(0.00207 \mu \mathrm{g} \mathrm{L}^{-1}\right)$ ions. The same limit of quantification $\left(0.00207 \mu \mathrm{g} \mathrm{L}^{-1}\right)$ for $\mathrm{Pb}^{2+}$ ions was also obtained for the graphene dot microsensors modified with $\mathrm{Fe}(\mathrm{II}) \mathrm{Pc}$ or modified with $\mathrm{Ni}(\mathrm{II}) \mathrm{Pc}$, and for the graphite dot microsensor modified with Fe(II)Pc. 

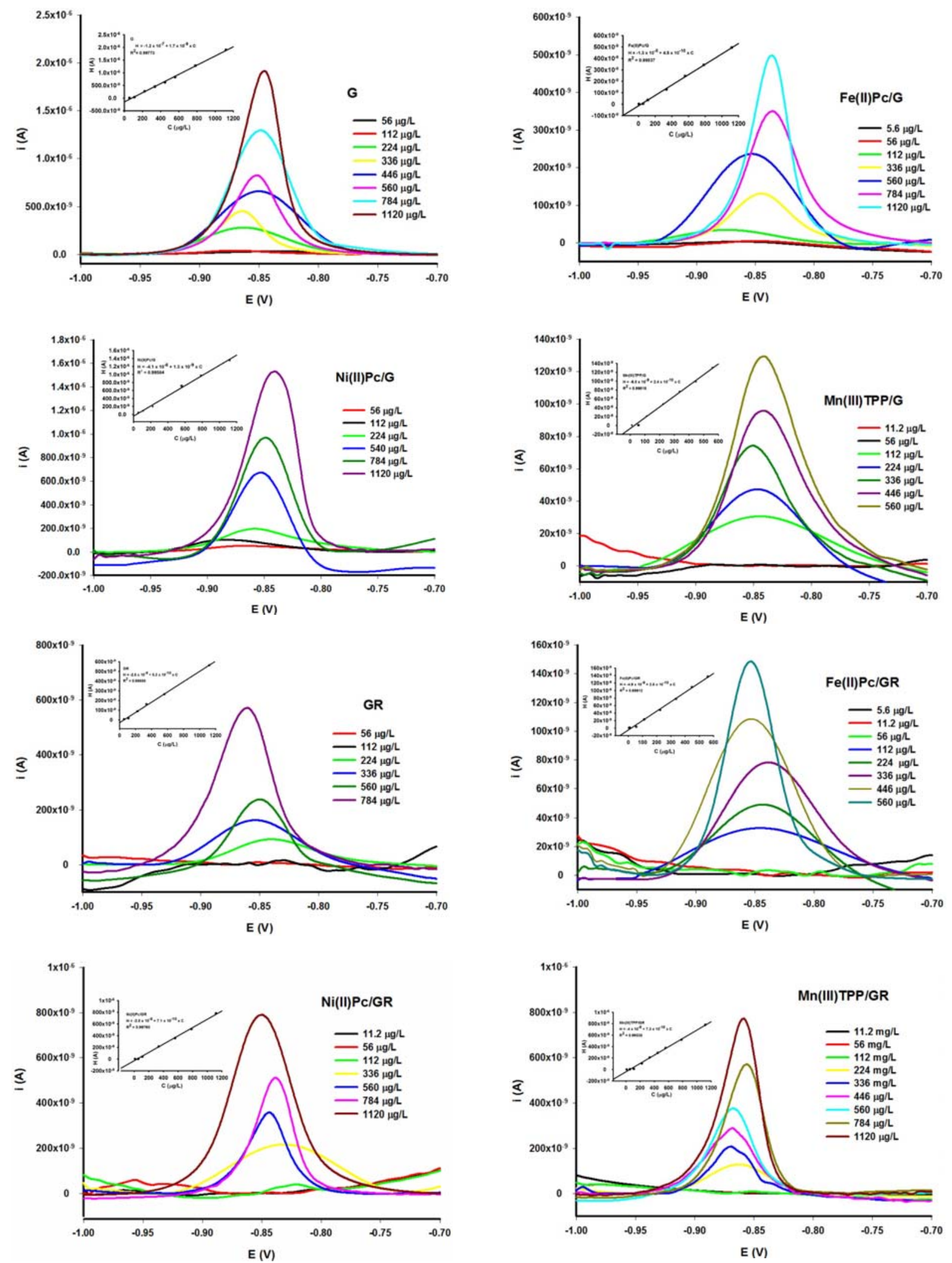

Fig. 4 - The calibration curves of the dot microsensors based on: a) G; b) Fe(II)Pc/G; c) Ni(II)Pc/G; d) Mn(III)TPP/G; e) GR; f) $\mathrm{Fe}(\mathrm{II}) \mathrm{Pc} / \mathrm{GR}$; g) $\mathrm{Ni}(\mathrm{II}) \mathrm{Pc} / \mathrm{GR}$; h) $\mathrm{Mn}(\mathrm{III}) \mathrm{TPP} / \mathrm{GR}$ for the assay of $\mathrm{Cd}^{2+}$ ions; insert: the peak height (A) vs. the concentration of $\mathrm{Cd}^{2+}$ ions $\left(\mu \mathrm{g} \mathrm{L}^{-1}\right)$. 

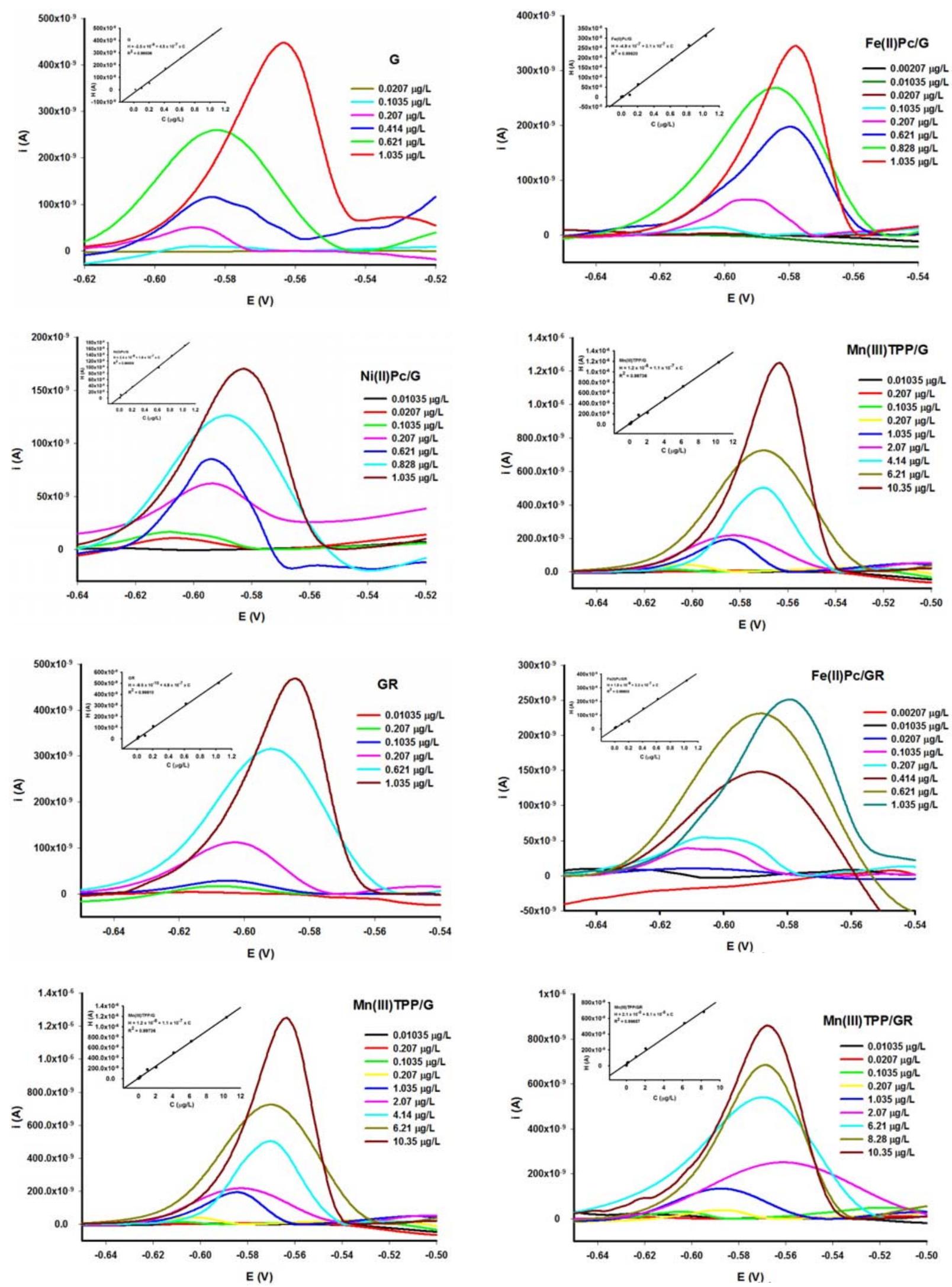

Fig. 5 - The calibration curves of the dot microsensors based on: a) G; b) Fe(II)Pc/G; c) Ni(II)Pc/G; d) Mn(III)TPP/G; e) GR; f) $\mathrm{Fe}(\mathrm{II}) \mathrm{Pc} / \mathrm{GR}$; g) $\mathrm{Ni}(\mathrm{II}) \mathrm{Pc} / \mathrm{GR}$; h) $\mathrm{Mn}(\mathrm{III}) \mathrm{TPP} / \mathrm{GR}$ for the assay of $\mathrm{Pb}^{2+}$ ions; insert: the peak height (A) vs. the concentration of $\mathrm{Pb}^{2+}$ ions $\left(\mu \mathrm{g} \mathrm{L}{ }^{-1}\right)$. 
Table 2

Response characteristics of the electrodes used for determination of $\mathrm{Cd}^{2+}$ and $\mathrm{Pb}^{2+}$

\begin{tabular}{|c|c|c|c|c|c|c|}
\hline $\begin{array}{l}\text { Heavy } \\
\text { Metal }\end{array}$ & Sensors & $\begin{array}{l}\text { Equation of } \\
\text { calibration* }\end{array}$ & $\mathbf{R}$ & $\begin{array}{l}\text { Sensitivity } \\
\left(\mathrm{A} \mu \mathrm{gL}^{-1}\right)\end{array}$ & $\begin{array}{l}\text { Linear conc. } \\
\text { range }\left(\mu \mathrm{g} \mathrm{L}^{-1}\right)\end{array}$ & $\begin{array}{c}\text { Limit of } \\
\text { quantification } \\
\left(\mu \mathrm{g} \mathrm{L}^{-1}\right)\end{array}$ \\
\hline \multirow{8}{*}{$\mathrm{Cd}^{2+}$} & $\mathrm{G}$ & $\mathrm{H}=-1.2 \times 10^{-7}+1.7 \times 10^{-9} \times C$ & 0.99886 & $1.7 \times 10^{-9}$ & $56-1120$ & 56 \\
\hline & $\mathrm{Fe}(\mathrm{II}) \mathrm{Pc} / \mathrm{G}$ & $\mathrm{H}=-1.3 \times 10^{-8}+4.5 \times 10^{-10} \times C$ & 0.99918 & $4.5 \times 10^{-10}$ & $5.6-1120$ & 5.6 \\
\hline & $\mathrm{Ni}(\mathrm{II}) \mathrm{Pc} / \mathrm{G}$ & $\mathrm{H}=-4.1 \times 10^{-8}+1.3 \times 10^{-9} \times C$ & 0.99792 & $1.3 \times 10^{-9}$ & $56-1120$ & 56 \\
\hline & $\mathrm{Mn}(\mathrm{III}) \mathrm{TPP} / \mathrm{G}$ & $\mathrm{H}=-6.8 \times 10^{-9}+2.4 \times 10^{-10} \times C$ & 0.99757 & $2.4 \times 10^{-10}$ & $11.2-560$ & 11.2 \\
\hline & GR & $\mathrm{H}=-2.8 \times 10^{-8}+5.3 \times 10^{-10} \mathrm{xC}$ & 0.99904 & $5.3 \times 10^{-10}$ & $56-1120$ & 56 \\
\hline & $\mathrm{Fe}(\mathrm{II}) \mathrm{Pc} / \mathrm{GR}$ & $\mathrm{H}=-4.9 \times 10^{-9}+2.5 \times 10^{-10} \times C$ & 0.99806 & $2.5 \times 10^{-10}$ & $56-560$ & 56 \\
\hline & $\mathrm{Ni}(\mathrm{II}) \mathrm{Pc} / \mathrm{GR}$ & $\mathrm{H}=-2.8 \times 10^{-8}+7.1 \times 10^{-10} \mathrm{xC}$ & 0.99880 & $7.1 \times 10^{-10}$ & $11.2-1120$ & 11.2 \\
\hline & $\mathrm{Mn}(\mathrm{III}) \mathrm{TPP} / \mathrm{GR}$ & $\mathrm{H}=-4.0 \times 10^{-8}+7.3 \times 10^{-10} \times C$ & 0.99769 & $7.3 \times 10^{-10}$ & $11.2-1120$ & 11.2 \\
\hline \multirow{8}{*}{$\mathrm{Pb}^{2+}$} & $\mathrm{G}$ & $\mathrm{H}=-2.5 \times 10^{-8}+4.5 \times 10^{-7} \times C$ & 0.99753 & $4.5 \times 10^{-7}$ & $0.0207-1.035$ & 0.0207 \\
\hline & $\mathrm{Fe}(\mathrm{II}) \mathrm{Pc} / \mathrm{G}$ & $\mathrm{H}=-4.9 \times 10^{-9}+3.1 \times 10^{-7} \times C$ & 0.99810 & $3.1 \times 10^{-7}$ & $0.00207-1.035$ & 0.00207 \\
\hline & $\mathrm{Ni}(\mathrm{II}) \mathrm{Pc} / \mathrm{G}$ & $\mathrm{H}=2.4 \times 10^{-9}+1.6 \times 10^{-7} \times C$ & 0.99905 & $1.6 \times 10^{-7}$ & $0.01035-1.035$ & 0.01035 \\
\hline & $\mathrm{Mn}(\mathrm{III}) \mathrm{TPP} / \mathrm{G}$ & $\mathrm{H}=1.2 \times 10^{-8}+1.1 \times 10^{-7} \times C$ & 0.99868 & $1.1 \times 10^{-7}$ & $0.01035-10.35$ & 0.01035 \\
\hline & GR & $\mathrm{H}=-9.5 \times 10^{-10}+4.9 \times 10^{-7} \times C$ & 0.99805 & $4.9 \times 10^{-7}$ & $0.01035-1.035$ & 0.01035 \\
\hline & $\mathrm{Fe}(\mathrm{II}) \mathrm{Pc} / \mathrm{GR}$ & $\mathrm{H}=1.8 \times 10^{-9}+3.3 \times 10^{-7} \times C$ & 0.99804 & $3.3 \times 10^{-7}$ & $0.00207-1.035$ & 0.00207 \\
\hline & $\mathrm{Ni}(\mathrm{II}) \mathrm{Pc} / \mathrm{GR}$ & $\mathrm{H}=-2.0 \times 10^{-8}+8.7 \times 10^{-7} \times C$ & 0.99761 & $8.7 \times 10^{-7}$ & $0.00207-1.035$ & 0.00207 \\
\hline & $\mathrm{Mn}(\mathrm{III}) \mathrm{TPP} / \mathrm{GR}$ & $\mathrm{H}=-2.1 \times 10^{-8}+8.1 \times 10^{-8} \times C$ & 0.99923 & $8.1 \times 10^{-8}$ & $0.01035-10.35$ & 0.01035 \\
\hline
\end{tabular}

$* \mathrm{H}$ is the peak height $(\mathrm{A}) ; \mathrm{C}$ is the concentration $\left(\mu \mathrm{g} \mathrm{L}^{-1}\right)$
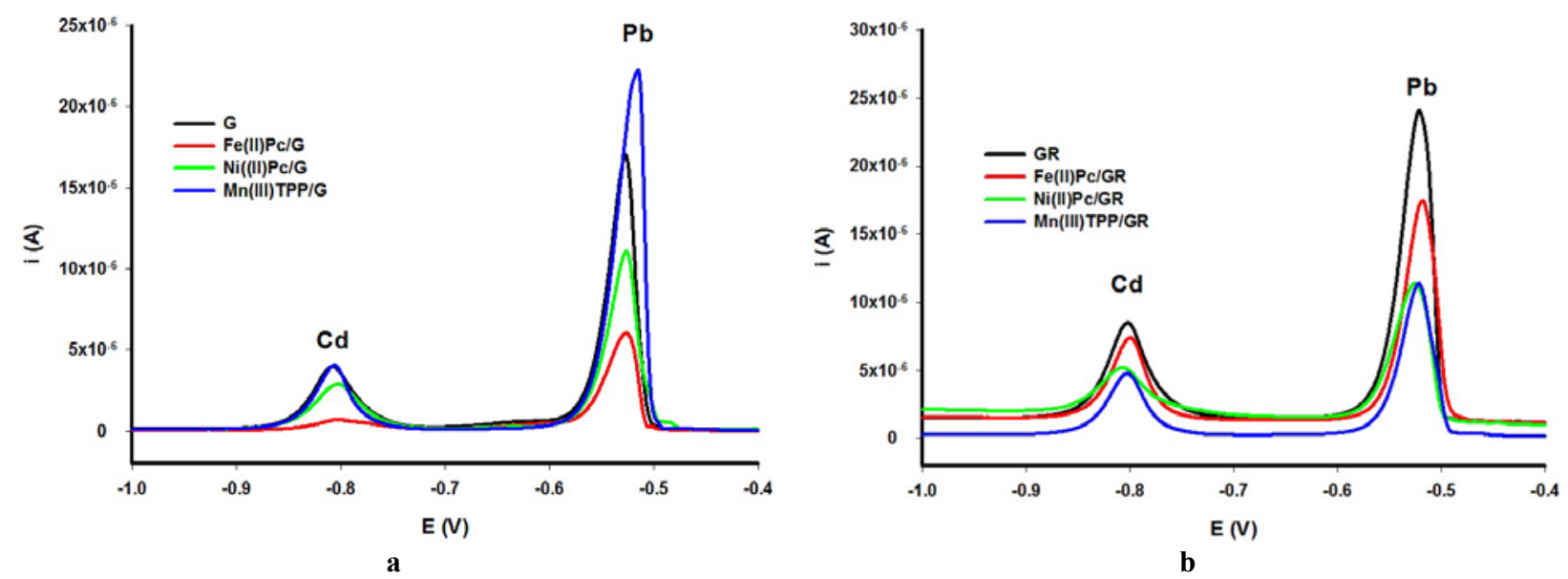

Fig. 6 - Differential pulse anodic stripping voltammetry obtained for a mix solution of $10^{-4} \mathrm{~mol} \mathrm{~L}^{-1} \mathrm{Cd}^{2+}$ and $10^{-4} \mathrm{~mol} \mathrm{~L}^{-1} \mathrm{~Pb}^{2+}$ for $\mathrm{KCl} \mathrm{pH}=2$ electrolyte for: a) $\mathrm{G}, \mathrm{Fe}(\mathrm{II}) \mathrm{Pc} / \mathrm{G}, \mathrm{Ni}(\mathrm{II}) \mathrm{Pc} / \mathrm{G}, \mathrm{Mn}(\mathrm{III}) \mathrm{TPP} / \mathrm{G}$ dot microsensors, and b) GR, $\mathrm{Fe}(\mathrm{II}) \mathrm{Pc} / \mathrm{GR}, \mathrm{Ni}(\mathrm{II}) \mathrm{Pc} / \mathrm{GR}$, $\mathrm{Mn}(\mathrm{III}) \mathrm{TPP} / \mathrm{GR}$ dot microsensors.

\section{Simultaneous determination of $\mathrm{Cd}^{2+}$ and $\mathrm{Pb}^{2+}$ ions}

The DPV voltammograms with simultaneous determination of $\mathrm{Cd}^{2+}$ and $\mathrm{Pb}^{2+}$ ions were presented in Figure 6, using a mixed solution containing $10^{-4}$ mol L ${ }^{-1} \mathrm{Cd}^{2+}$ and $\mathrm{Pb}^{2+}$ ions in $0.1 \mathrm{~mol} \mathrm{~L}^{-1} \mathrm{KCl}$ PBS $\mathrm{pH}=2$. Table 3 shows the condition for these determinations, for all dot microsensors. It is clear from the DPV voltammograms in Figure 6 that a good separation was obtained for $\mathrm{Cd}^{2+}$ and $\mathrm{Pb}^{2+}$ ions in the mixed solution. The method is more selective for $\mathrm{Pb}^{2+}$ ions.

\section{Real samples}

Different types of waters (waste water, surface water, drinking water from spring water, ground water) from different catchments areas were used for analytical determination of $\mathrm{Cd}^{2+}$ and $\mathrm{Pb}^{2+}$ ions. Buffered water samples $(1: 1, \mathrm{v} / \mathrm{v})$ were screened using the proposed dot microsensors before and after the addition of certain amounts of $\mathrm{Cd}^{2+}$ and $\mathrm{Pb}^{2+}$. The results obtained, using differential pulse anodic stripping voltammetry, as presented in Tables 4 and 5 excellently compared with the SR EN ISO 11885:2009 standard method (inductively coupled plasma atomic emission spectroscopy). It can be seen that all dot microsensors gave very good results for the determination of $\mathrm{Cd}^{2+}$ and $\mathrm{Pb}^{2+}$ ions in different types of water from different water catchment areas, with the relative standard deviation (RSD\%) of less than $0.29 \%$. 
Table 3

Experimental conditions for the determination of ions of $\mathrm{Pb}^{2+}$ and $\mathrm{Cd}^{2+}$ ions in mixture

\begin{tabular}{c|c|c|c|c}
\hline Censor & \multirow{2}{*}{ Conditions } & \multirow{2}{*}{ PBS } & $\begin{array}{c}\text { Reduction potential } \\
\text { (V) }\end{array}$ & $\begin{array}{c}\text { Reduction time } \\
\text { (s) }\end{array}$ \\
\hline $\mathrm{G}$ & $\mathrm{KCl}$ & $\mathrm{pH}=2$ & -1.4 & 180 \\
$\mathrm{Fe}(\mathrm{II}) \mathrm{Pc} / \mathrm{G}$ & $\mathrm{KCl}$ & $\mathrm{pH}=2$ & -1.3 & 210 \\
$\mathrm{Ni}(\mathrm{II}) \mathrm{Pc} / \mathrm{G}$ & $\mathrm{KCl}$ & $\mathrm{pH}=2$ & -1.4 & 180 \\
$\mathrm{Mn}(\mathrm{III}) \mathrm{TPP} / \mathrm{G}$ & $\mathrm{KCl}$ & $\mathrm{pH}=2$ & -1.2 & 180 \\
$\mathrm{GR}$ & $\mathrm{KCl}$ & $\mathrm{pH}=2$ & -1.2 & 210 \\
$\mathrm{Fe}(\mathrm{II}) \mathrm{Pc} / \mathrm{GR}$ & $\mathrm{KCl}$ & $\mathrm{pH}=2$ & -1.2 & 180 \\
$\mathrm{Ni}(\mathrm{II}) \mathrm{Pc} / \mathrm{GR}$ & $\mathrm{KCl}$ & $\mathrm{pH}=2$ & -1.5 & 240 \\
$\mathrm{Mn}(\mathrm{III}) \mathrm{TPP} / \mathrm{GR}$ & $\mathrm{KCl}$ & $\mathrm{pH}=2$ & -1.2 & 180 \\
\hline
\end{tabular}

$\mathrm{PBS}=$ phosphate buffer solution

Table 4

Sample results $\left(\mu \mathrm{g} \mathrm{L}^{-1}\right)$ from different types of water samples for $\mathrm{Cd}^{2+}$

\begin{tabular}{|c|c|c|c|c|c|c|c|c|}
\hline & \multicolumn{2}{|c|}{ Sample 1} & \multicolumn{2}{|c|}{ Sample 2} & \multirow{2}{*}{\multicolumn{2}{|c|}{$\begin{array}{c}\text { Sample } 3 \\
\begin{array}{c}\text { drinking water from } \\
\text { spring water }\end{array} \\
\end{array}$}} & \multicolumn{2}{|c|}{ Sample 4} \\
\hline & \multicolumn{2}{|c|}{ wastewater } & \multicolumn{2}{|c|}{ surface water } & & & \multicolumn{2}{|c|}{ groundwater } \\
\hline & ASV & $\begin{array}{l}\text { ICP- } \\
\text { OES }\end{array}$ & ASV & $\begin{array}{l}\text { ICP- } \\
\text { OES }\end{array}$ & ASV & $\begin{array}{l}\text { ICP- } \\
\text { OES }\end{array}$ & ASV & $\begin{array}{l}\text { ICP- } \\
\text { OES }\end{array}$ \\
\hline $\mathrm{G}$ & $0.46 \pm 0.002$ & 0.5 & $0.46 \pm 0.002$ & 0.5 & $0.49 \pm 0.003$ & 0.5 & $0.36 \pm 0.002$ & 0.4 \\
\hline $\mathrm{Fe}(\mathrm{II}) \mathrm{Pc} / \mathrm{G}$ & $0.48 \pm 0.003$ & 0.5 & $0.43 \pm 0.001$ & 0.5 & $0.44 \pm 0.003$ & 0.5 & $0.37 \pm 0.001$ & 0.4 \\
\hline $\mathrm{Ni}(\mathrm{II}) \mathrm{Pc} / \mathrm{G}$ & $0.45 \pm 0.002$ & 0.5 & $0.47 \pm 0.004$ & 0.5 & $0.47 \pm 0.003$ & 0.5 & $0.38 \pm 0.003$ & 0.4 \\
\hline $\mathrm{Mn}(\mathrm{III}) \mathrm{TPP} / \mathrm{G}$ & $0.48 \pm 0.002$ & 0.5 & $0.47 \pm 0.002$ & 0.5 & $0.49 \pm 0.004$ & 0.5 & $0.39 \pm 0.008$ & 0.4 \\
\hline GR & $0.45 \pm 0.003$ & 0.5 & $0.47 \pm 0.002$ & 0.5 & $0.46 \pm 0.004$ & 0.5 & $0.37 \pm 0.004$ & 0.4 \\
\hline $\mathrm{Fe}(\mathrm{II}) \mathrm{Pc} / \mathrm{GR}$ & $0.46 \pm 0.004$ & 0.5 & $0.46 \pm 0.002$ & 0.5 & $0.46 \pm 0.002$ & 0.5 & $0.37 \pm 0.004$ & 0.4 \\
\hline Ni(II)Pc/GR & $0.46 \pm 0.028$ & 0.5 & $0.46 \pm 0.017$ & 0.5 & $0.49 \pm 0.011$ & 0.5 & $0.38 \pm 0.022$ & 0.4 \\
\hline Mn(III)TPP/GR & $0.45 \pm 0.005$ & 0.5 & $0.43 \pm 0.005$ & 0.5 & $0.46 \pm 0.005$ & 0.5 & $0.35 \pm 0.004$ & 0.4 \\
\hline
\end{tabular}

ASV $=$ anodic stripping voltammetry

ICP-OES = Inductively coupled plasma atomic emission spectroscopy

Relative standard deviation for 5 measurements $(n=5)$

Table 5

Sample results $\left(\mu \mathrm{g} \mathrm{L}^{-1}\right)$ from different types of water samples for $\mathrm{Pb}^{2+}$

\begin{tabular}{|c|c|c|c|c|c|c|c|c|}
\hline & \multicolumn{2}{|c|}{ Sample 1} & \multicolumn{2}{|c|}{ Sample 2} & \multicolumn{2}{|c|}{ Sample 3} & \multicolumn{2}{|c|}{ Sample 4} \\
\hline & \multicolumn{2}{|c|}{ wastewater } & \multicolumn{2}{|c|}{ surface water } & \multicolumn{2}{|c|}{$\begin{array}{l}\text { drinking water from } \\
\text { spring water }\end{array}$} & \multicolumn{2}{|c|}{ groundwater } \\
\hline & ASV & $\begin{array}{l}\text { ICP- } \\
\text { OES }\end{array}$ & $\mathbf{A S V}^{*}$ & $\begin{array}{l}\text { ICP- } \\
\text { OES }\end{array}$ & ASV $^{*}$ & $\begin{array}{l}\text { ICP- } \\
\text { OES }\end{array}$ & $\mathbf{A S V}^{*}$ & $\begin{array}{l}\text { ICP- } \\
\text { OES }\end{array}$ \\
\hline $\mathrm{G}$ & $5.46 \pm 0.157$ & 5.5 & $1.37 \pm 0.092$ & 1.40 & $1.04 \pm 0.081$ & 1.10 & $0.58 \pm 0.113$ & 0.6 \\
\hline $\mathrm{Fe}(\mathrm{II}) \mathrm{Pc} / \mathrm{G}$ & $5.49 \pm 0.277$ & 5.5 & $1.39 \pm 0.062$ & 1.40 & $1.09 \pm 0.007$ & 1.10 & $0.59 \pm 0.012$ & 0.6 \\
\hline $\mathrm{Ni}(\mathrm{II}) \mathrm{Pc} / \mathrm{G}$ & $5.48 \pm 0.291$ & 5.5 & $1.38 \pm 0.095$ & 1.40 & $1.04 \pm 0.034$ & 1.10 & $0.48 \pm 0.0223$ & 0.6 \\
\hline $\mathrm{Mn}(\mathrm{III}) \mathrm{TPP} / \mathrm{G}$ & $5.16 \pm 0.138$ & 5.5 & $1.35 \pm 0.109$ & 1.40 & $1.09 \pm 0.045$ & 1.10 & $0.53 \pm 0.073$ & 0.6 \\
\hline GR & $5.41 \pm 0.102$ & 5.5 & $1.34 \pm 0.053$ & 1.40 & $0.90 \pm 0.009$ & 1.10 & $0.55 \pm 0.008$ & 0.6 \\
\hline $\mathrm{Fe}(\mathrm{II}) \mathrm{Pc} / \mathrm{GR}$ & $5.42 \pm 0.193$ & 5.5 & $1.36 \pm 0.078$ & 1.40 & $1.02 \pm 0.014$ & 1.10 & $0.59 \pm 0.0159$ & 0.6 \\
\hline $\mathrm{Ni}(\mathrm{II}) \mathrm{Pc} / \mathrm{GR}$ & $5.31 \pm 0.201$ & 5.5 & $1.38 \pm 0.041$ & 1.40 & $0.98 \pm 0.037$ & 1.10 & $0.58 \pm 0.0162$ & 0.6 \\
\hline Mn(III)TPP/GR & $5.21 \pm 0.179$ & 5.5 & $1.35 \pm 0.069$ & 1.40 & $1.06 \pm 0.059$ & 1.10 & $0.54 \pm 0.0521$ & 0.6 \\
\hline
\end{tabular}

ASV $=$ anodic stripping voltammetry

ICP-OES $=$ Inductively coupled plasma atomic emission spectroscopy

Relative standard deviation for 5 measurements $(n=5)$

\section{CONCLUSION}

Several dot microsensors based on graphite or graphene unmodified or modified with $\mathrm{Fe}(\mathrm{II}) \mathrm{Pc}$, $\mathrm{Ni}(\mathrm{II}) \mathrm{Pc}$ and $\mathrm{Mn}(\mathrm{III}) \mathrm{TPP}$ were proposed for the determination of $\mathrm{Cd}^{2+}$ and $\mathrm{Pb}^{2+}$ ions. It can be seen that for all dot microsensors good correlation coefficients were obtained. The highest sensitivity for the dot microsensors was recorded for $\mathrm{Pb}^{2+}$ ions, in comparison with the determination for the 
$\mathrm{Cd}^{2+}$ ions. A good separation was obtained as expected. All dot microsensors have good results for the determination of $\mathrm{Cd}^{2+}$ and $\mathrm{Pb}^{2+}$ ions in various water catchments areas.

Acknowledgements. The authors gratefully acknowledge the Roumanian National Authority for Scientific Research, UEFISCDI for financial support, under grants PN-III-P2-2.1PED-2016-0181, PN-III-P4-ID-PCE-2016-0050 and the National Research and Development Institute for Industrial Ecology - INCD-ECOIND Bucharest for standard ISOcertified samples.

\section{REFERENCES}

1. http://www.who.int/ipcs/publications/chemicals-publichealth-impact/en/, the public health impact of chemicals: known's and unknowns, 2016.

2. http://www.who.int/topics/water/en/.

3. E. Suren, S. Yilmaz, M. Turkoglu and S. Kaya, Environ. Monit. Assess., 2007, 125, 91-98.

4. Directive 2013/35/EU of the European Parliament and of the Council, 2013.

5. U.S. EPA National Primary Drinking Water Regulations 2009.

6. G. Spijker, G. Mol and L. Posthuma, Geochem. Health., 2011, 33, 409-426.

7. J. Grigg, Arch. Dis. Child., 2004, 89, 244-250.

8. A. Ostadrahimi, L. Payahoo, M. H. Somi, S.H. Hashemzade, A. Esfahani, M. Asgharijafarabadi, M. Mobasseri, N. Samadi, S. Faraji and Y. KhajeBishak, Polish Annal. Med., 2017, 24, 133-137.

9. Y. K. Bishak, L. Payahoo, A. Osatdrahimi and A. Nourazarian, Asian. Pac. J. Cancer. P., 2015, 16, 9-21.

10. T. Inaba, E. Kobayashi, Y Suwazono, M. Uetani, M. Oishi, H. Nakagawa and K. Nogawa. Toxicol. Lett., 2005, 159, 192-201.

11. M. Fukushima, A. Ishizaki, K. Nogawa, M. Sakamoto and E. Kobayashi, Jpn. J. Pub. Health., 1974, 21, 65-73.

12. W. Swaddiwudhipong, P. Mahasakpan, W. Jeekeeree, T. Funkhiewa, R. Sanjum, T. Apiwatpaiboon and I. Phopueng, Environ. Res., 2015, 136, 82-87.

13. X. Chen, G. Zhu, T. Jin, L. Lei and Y. Liang, Environ. Toxicol. Phar., 2011, 32, 46-53.

14. V. Vella, R. Malaguarnera, R. Lappano, M. Maggiolini and A. Belfiore, Mol. Cell. Endocrinol., 2017, 457, 57 72.

15. L. B. Priya, R. Baskaran, P. Elangovan, V. Dhivya, C-Y. Huang and V. V. Padma, Biomed. Pharmacother., 2017, 87, 280-287.

16. Y. Cao, M. A. Skaug, O. Andersen and J. Aaseth, J. Trace. Elem. Med. Bio., 2015, 31, 188-192.
17. A. Santurtúna, M. Delgado-Alvarado, A. Villar and J. Riancho, Med. Clin., 2016, 147, 481-487.

18. J. A. Santiago and J. A. Potashkin, Trends. Mol. Med., 2013, 19, 176-186.

19. S. J. S. Flora and S. K. Tandon, Toxicology., 1990, 64, 129-139.

20. A. D. Woolf, R. Goldman and D. C. Bellinger, Pediatr. Clin. N. Am., 2007, 54, 271-294.

21. M. Markowitz, Curr. Probl. Pediatr., 2000, 30, 62-70.

22. H. L. Haust, M. Inwood, J. D. Spence, H. C. Poon and F. Peter, Clin. Biochem. 1989, 22, 189-196.

23. H. M. Korashy, I. M. Attafi, K. S. Famulski, S. A. Bakheet, M. M. Hafez, A. M. S Alsaad and A. R. M Al-Ghadeer, Environ. Pollut., 2017, 221, 64-74.

24. K. Asaduzzaman, M. Uddin Khandaker, N. A. B. Baharudin, Y. Bin Mohd Amin, M. S. Farook, D. A. Bradley and O. Mahmoud, Chemosphere., 2017, 176, 221-230.

25. M. N. Islam, H-Y Jung and J. H Park, J. Environ. Manage., 2015, 63, 262-269.

26. A. K. Malik, V. Kaur and N. Verm, Talanta, 2006, 68, 842-849.

27. A. Zhang, L. Wang, S. Zhao, X. Yang, Q. Zhao, X. Zhang and X. Yuan, Regional Studies in Marine Science., 2017, $11,32-42$.

28. L. Wang, A. Li and Y. Chang, Chem. Eng. J., 2016, 297, $1-10$.

29. L. Makedonski, K. Peycheva and M. Stancheva, Food Control., 2017, 72, 313-318.

30. H. Li, L. Lin, S. Ye, H. Li and J. Fan, Mar. Pollut. Bul., 2017, 117, 499-506.

31. J. Vukovic, M. A. Avidad and L. F. Capitán-Vallvey, Talanta, 2012, 94, 123- 132.

32. N. A. Azmi and S. C. Low, J. Water Proc. Eng., 2017, $15,37-42$.

33. X. Li, H. Wen, Q. Fu, D. Peng, J. Yu, Q. Zhang and X. Huang, Appl. Surf. Sci., 2016, 36, 7-12.

34. M. A. Al-Ghouti, M. A. M. Khraisheh and M. Tutuji, Chem. Eng. J., 2004, 104, 83-91.

35. K. Keawkim, S. Chuanuwatanakul, O. Chailapakul and S. Motomizu, Food Control., 2013, 31, 14-21.

36. C. Chen, X Niu, Y. Chai, H. Zhao and M. Lan, Sensor. Actuat. B: Chem., 2013, 178, 339-342.

37. G. H. Hwang, W. K. Han, J. S. Park and S. G. Kang, Talanta, 2008, 76, 301-308.

38. J. C. Quintana, F. Arduini, A. Amine, F. Punzo, G. Li Destri, C. Bianchini, D. Zane, A. Curulli, G. Palleschi and D. Moscone, Anal. Chim. Acta., 2011, 707, 171- 177.

39. C. Parat, S. Betelu, L. Authier and M. Potin-Gautier, Anal. Chim. Acta., 2006, 573-574, 14-19.

40. S. Betelu, C. Parat, N. Petrucciani, A. Castetbon, L. Authier and M. Potin-Gautier, Electroanal., 2007, 19, $399-402$.

41. C. Pérez-Ràfols, N. Serrano, J. M. Díaz-Cruz, C. Ariño and M Esteba, Talanta, 2016, 155, 8-13. 
